Secular Trends and Climate Drift in Coupled Ocean-Atmosphere General Circulation Models

C. C. Covey, P. J. Gleckler, T. J. Phillips, D. C. Bader

December 1, 2004

Journal of Geophysical Research 
This document was prepared as an account of work sponsored by an agency of the United States Government. Neither the United States Government nor the University of California nor any of their employees, makes any warranty, express or implied, or assumes any legal liability or responsibility for the accuracy, completeness, or usefulness of any information, apparatus, product, or process disclosed, or represents that its use would not infringe privately owned rights. Reference herein to any specific commercial product, process, or service by trade name, trademark, manufacturer, or otherwise, does not necessarily constitute or imply its endorsement, recommendation, or favoring by the United States Government or the University of California. The views and opinions of authors expressed herein do not necessarily state or reflect those of the United States Government or the University of California, and shall not be used for advertising or product endorsement purposes. 


\section{Secular Trends and Climate Drift in Coupled Ocean- Atmosphere General Circulation Models}

Curt Covey, Peter J. Gleckler, Thomas J. Phillips and David C. Bader

Program for Climate Model Diagnosis and Intercomparison Mail Code L-103

Lawrence Livermore National Laboratory

Livermore, CA 94550

Email: covey1@IInl.gov

prepared for submission to Climate Dynamics

23 November 2004 


\begin{abstract}
Coupled ocean-atmosphere general circulation models (coupled GCMs) with interactive sea ice are the primary tool for investigating possible future global warming and numerous other issues in climate science. A long-standing problem with such models is that when different components of the physical climate system are linked together, the simulated climate can drift away from observations unless constrained by ad hoc adjustments to interface fluxes. However, eleven modern coupled GCMs - including three that do not employ flux adjustments - behave much better in this respect than the older generation of models. Surface temperature trends in control run simulations (with external climate forcing such as solar brightness and atmospheric carbon dioxide held constant) are small compared with observed trends, which include $20^{\text {th }}$ century climate change due to both anthropogenic and natural factors. Sea ice changes in the models are dominated by interannual variations. Deep ocean temperature and salinity trends are small enough for model control runs to extend over 1000 simulated years or more, but trends in some regions, most notably the Arctic, are inconsistent among the models and may be problematic.
\end{abstract}




\section{Introduction}

Secular climate trends have long been a problematic feature of coupled ocean-atmosphere general circulation models (coupled GCMs). When coupled GCMs came into widespread use in the 1980 s, one concern was that simulated climates would drift rapidly to unrealistic states. This climate drift problem occurs even in "control run" simulations with no changes in external climate forcing such as solar luminosity or greenhouse gas concentrations. The problem can be made less severe by ad hoc adjustments to air-sea fluxes. The mid-1990s assessment report of the Intergovernmental Panel on Climate Change (IPCC) noted this problem (Gates et al., 1996), but the subsequent IPCC Third Assessment Report (TAR) stated, "Some non-flux adjusted models are now able to maintain stable climatologies of comparable quality to flux adjusted models" (McAvaney et al., 2001). In this paper, we confirm and extend the IPCC's finding by examining model output from the most recent phase of the Coupled Model Intercomparison Project.

Results presented below are extracted from an appraisal of climate models by the Program for Climate Model Diagnosis and Intercomparison (AchutaRao et al. 2004, hereafter "2004 appraisal document"). We intend to perform a comprehensive appraisal of climate models approximately every two years. Motivation for this idea arose from the perceived needs of the modeling groups and the broader climate research community to document progress more frequently than provided by the IPCC assessment reports. The appraisal, together with this paper and others derived from the appraisal, provide a "snapshot" of the climate models in our database, many of which are a few years old. Model development is an ongoing activity, and nearly all of the models included in our database have been improved since these simulations were completed. In addition, the pace of model development differs among modeling institutions. Consequently, while one group's model may be viewed as "lagging" its peers in terms of completeness or sophistication, that same group may be viewed as leading the field in the near future following a period of intense development.

Section 2 of this paper provides background on the models used to produce the simulations in our database. Section 3 presents our analysis of climate drift in model control runs. We focus mainly on near-surface temperature but also include sea ice, and deep ocean temperature and salinity. A brief summary and discussion of our results appears in Section 4.

\section{Database}

The climate simulations analyzed in this paper are control runs from the latest group of submissions to the Coupled Model Intercomparison Project, or CMIP. This phase of CMIP is called CMIP2+ because it collected more extensive output than the previous phase, which was called CMIP2. An overview of the CMIP2 output was provided by Covey et al. (2003, hereafter "CMIP2 overview"). The eleven coupled GCMs that provided CMIP2+ output are described in Table 1. Comparison with Table 1 of the CMIP2 overview reveals that two of these models, BCM Version 1 and ECHO-G, are new to CMIP2+. (Thus far, only ocean variables from the BCM have been provided to CMIP.) Three CMIP2+ models-CCCma_CGCM2, CCSM2.0 and MRI_CGCM2.3-are 
updated versions of models that participated in CMIP2 (CCCma_CGCM1, CSM1 and MRI_CGCM1 respectively). The remaining six CMIP2+ models are identical to their CMIP2 counterparts. Thus, comparison of the CMIP2+ results with the CMIP2 overview provides some opportunity for assessment of model improvements between the times that CMIP2 and CMIP2+ output was collected. Note, however, the considerable variation of CMIP2+ model "vintage" given in Table 1.

Both the CMIP2 and CMIP2+ models typify the current generation of coupled GCMs. Dynamics of the atmosphere and ocean components of climate system are based on the global primitive equations - coupled partial differential equations that predict fluid flow on a rotating sphere. Also, the temperature and thickness of sea ice as well as the temperature and hydrology of the land are predicted variables. The models thus account, in some fashion, for coupling of major components of the physical climate system, and so are suitable for examining potential secular global climate changes such as global warming or climate drift. In this respect, the models contrast with atmospheric GCMs run with sea surface temperature and sea ice prescribed to match present-day observations (AMIP-type models; see Gates et al. 1999), or coupled ocean-atmosphere models that are more geographically and / or physically constrained, and thus are designed for more limited objectives, e.g., prediction of El Nino phenomena with tropical sea surface temperatures computed by the model but extratropical SSTs prescribed.

While the details of the "spin-up" procedures are quite varied among the CMIP2+ models, most groups first ran the atmosphere and ocean components in stand-alone mode (often using information derived from the atmospheric spin-up as boundary forcing for the ocean) before initiating spin-up of the coupled system. The CCSM2.0 and HadCM3 were the chief exceptions to such a sequential procedure. In these models, spin-up of the coupled system proceeded directly after initialization of the atmosphere and ocean components from relevant climatologies. Indeed, the observational estimates of ocean temperature and salinity (e.g. Levitus, 1982; Levitus and Boyer, 1994; Levitus et al., 1995) figure prominently in the spin-up procedures of virtually all the models. Because the typical coupled spin-up period is less than $\sim 150$ years, the memory of these ocean climatologies probably is retained in the control runs of most CMIP2+ models.

Most of the CMIP2+ models employ some type of ocean-atmosphere flux adjustments (usually computed as part of the spin-up procedures) in order to limit nonphysical climate drift. Three models (CCSM2.0, HadCM3, and PCM) do not apply any flux adjustment, however. The other models adjust surface fluxes of heat, fresh water, and momentum as noted in column 4 of Table 1 .

Many of the control runs supplied to our database begin immediately after the coupled spin-up period (in "Year 1"- -see column 6 of Table 1). However, the start of some archived control runs is $\sim 50-300$ years after the completion of the coupled spin-up (CCCma_CGCM2, CSIRO-Mk2, ECHAM4_OPYC3, ECHO-G, and HadCM3). The length of the archived control runs also ranges widely across the models: from 80 years (HadCM2) to 650 years (CCSM2.0). The diversity of the control runs, as well as the varying lengths of the corresponding spin-up periods, have potential impacts on the trends in ocean variables that are discussed below. 


\section{Control run variability and secular trends}

\subsection{Global and hemispheric means for surface temperature}

Before addressing the climate drift issue, we briefly consider the simulated climate variability that remains after secular trends are removed. (A thorough examination of climate variability in the CMIP2+ models is presented in the 2004 appraisal document.) Figure 1 shows power spectra of detrended global and annual mean surface air temperature. Each of the CMIP2+ models are represented except for the BCM, for which atmosphere output is not yet available. Observations compiled for the IPCC TAR are also included (Jones et al. 1999). The spectral density (vertical scale) gives the amount of temperature variance at each cyclic period (horizontal scale). We calculated the spectral density by methods described in Jenkins and Watts (1968), using auto-covariance with lags up to $1 / 4$ the length of each time series and a Tukey window $1 / 10$ as long as each time series.

The resulting CMIP2+ spectra displayed in the figure are quite similar to results from the earlier CMIP2 generation of models. The similarity is not surprising. As we discuss in the previous section, the CMIP2 and CMIP2+ models are an overlapping set. Power spectra for global and annual mean surface air temperature from the CMIP2 models are given in Fig. 17 of the CMIP2 overview. In both the CMIP2 overview and the present results, the models simulate variability that is generally less than or equal to that of the observations. The main exceptions to this rule (for both CMIP2 and CMIP2+) come from the HadCM2 and especially the GFDL_R30_c models at periods of $\sim 10$ years.

One would expect simulated variability that is less than observed - at least on longer time scales - for model control runs. By definition, control runs lack the time-evolving climate forcing (both natural and anthropogenic) that is implicit in the observed record. Thus control run simulations should give a lower bound to the actual climate system's variability. Some of the discrepancy, however, may be due to problems with the models themselves if they underestimate ENSO and other forms of internally generated climate variability.

Turning to the long-term trends of surface air temperature, Fig. 2 shows time series of annual and area-averaged means from each of the CMIP2+ models (except the BCM) and the IPCC TAR observations. Area averages are given separately for the Northern Hemisphere, the Southern Hemisphere and the entire globe. Note that during 1961-1991, the observed absolute temperature averaged $287 \mathrm{~K}$. The global mean temperatures of the CMIP2+ models lie between 285 and $287 \mathrm{~K}$. This result compares with 284-290 K reported in the CMIP2 overview.

When one examines secular trends in the CMIP2+ database, it is important to keep in mind that output from different models may come from different time segments within long control runs. For example, the CCCma CGCM2, ECHO-G and HadCM3 output in the CMIP2+ database is from near the beginning of these models' control runs, whereas control run output from the CCSM2.0, GFDL R30c and PCM extends for 300 simulated years. Institutions chose the time segment for their CMIP2+ control run output to match the time period for their $1 \%$ per year increasing atmospheric carbon dioxide scenario 
(part of the CMIP output not considered in this paper). This choice was necessary in order to permit comparison of the control run and increasing $\mathrm{CO}_{2}$ output, but secular trends are typically smaller during later times in model control runs. Accordingly, the results discussed below represent an upper bound on control run secular trends, and it would be inappropriate to draw conclusions from these results about which models are inherently more stable.

The observed global mean linear trend is $0.4 \mathrm{~K} /$ century for the full 138 years of available data (and $0.7 \mathrm{~K} /$ century for the $20^{\text {th }}$ century). With one exception, the CMIP2+ model control runs exhibit global mean linear trends that are a factor of 5 or more smaller in magnitude. As noted above, changes that are smaller than observed are expected for control runs, because these simulations don't include changes in climate forcing. The mean magnitude \pm standard deviation of the global mean trends for the CMIP2+ models is $0.08 \pm 0.12 \mathrm{~K} /$ century, similar to the CMIP2 results. The three CMIP2+ models that are not flux-adjusted-CCSM2.0, HadCM3 and PCM-have global mean trends of $-0.2,0.6$ and $0.2 \mathrm{~K} /$ century, respectively. These trends are comparable to those of the CMIP2 non-flux-adjusted models and are much smaller than those of the CMIP1 non-flux-adjusted models (mean magnitudes of 0.3 and $1.0 \mathrm{~K} /$ century respectively, according to the CMIP2 overview).

\subsection{Geographical distribution for surface temperature}

Evidently the newer generation of non-flux-adjusted models is able to maintain surface temperature "climate drift" within acceptable bounds for century-scale simulations, at least in a global or hemispheric mean sense. Does this statement also apply when we look at the individual grid points of models? Table 2 summarizes the sea surface temperature trends for the CMIP2+ models in two ways. The mean over the grid points is a global area average. It gives results for SST that are similar to those for global mean surface air temperature discussed above. The root-mean-square (RMS) over grid points

gives the typical magnitude of surface temperature trend at an individual grid point of each model (or observations). As with global and hemispheric means, the RMS trends are smaller than observed, as expected for control run simulations. This statement is true for both flux-adjusted and non-flux-adjusted models. The non-flux-adjusted CCSM2.0 and PCM are particularly noteworthy in this respect. SST trends of the third CMIP2+ non-flux-adjusted model, HadCM3, are also smaller than observed but are greater than those of the CCSM2.0 and PCM. As noted above, HadCM3 output in the CMIP2+ database comes from the beginning rather than the end of its control run, exaggerating its apparent climate drift.

A more detailed comparison of trends from the CCSM2.0 model, the PCM and observation is provided by Fig. 3. This shows that in the CCSM2.0 simulation, there are about as many areas of warming as of cooling, and the magnitude of the SST trend is everywhere smaller than $1 \mathrm{~K} /$ century. Trends for the PCM are somewhat greater (up to $\sim 1.6 \mathrm{~K}$ / century), with cooling near the North Pole and warming near the South Pole, but again there are about equal areas of warming and cooling. (Note that in the models, "sea surface temperature" near the poles is really ice surface temperature.) In contrast, for HadSST observations during 1898-1998 (Rayner et al. 2003) the linear trend at nearly all grid points is warming and the magnitude of the trend exceeds $2 \mathrm{~K} /$ century at some locations. Presumably this trend is mainly due to anthropogenic global warming, 
believed to dominate the climate record since the mid- $20^{\text {th }}$ century and not included in model control runs. Trend maps for the other CMIP2+ models (not shown) confirm this qualitative difference between control runs and observations.

\subsection{Ocean and sea ice}

Although our results demonstrate that climate drift for the CMIP2+ models is generally small in terms of near-surface temperature, the possibility remains that trends in the deep ocean could be problematic. The enormous capacity of the ocean to store heat and salt means that a model could be developing long-term problems at depth even as surface trends appear innocuous. Such was the case in at least one of the CMIP2 models (CSM1 - see below). In this section we examine the situation for the CMIP2+ models, with particular attention to models that were not flux-adjusted and thus might exhibit the worst problems.

Figure 4 shows total ocean volume-averaged salinity over time for the three CMIP2+ models that were not flux-adjusted. In all three models, the change in averaged salinity over $\sim 100$ years or more is exceedingly small. The HadCM3 exhibits a change of only 0.0005 ppt over 80 years despite the fact that its CMIP2+ output was taken from the beginning of its control run. Both the CCSM2.0 and PCM exhibit considerably smaller rates of salinity drift after the first few decades of their control runs. All three rates are much less than the steady $0.04 \mathrm{ppt} /$ century increase reported by Bryan (1998) for the CSM1. Similarly encouraging results (not shown) are evident for total ocean heat content. Long-term trends of this quantity are in the range $1-5 \times 10^{23} \mathrm{~J} /$ century for the three CMIP2+ non-flux-adjusted models. This rate of change may be somewhat greater than observed $\left(\sim 10^{23} \mathrm{~J}\right.$ over 40 years, according to Barnett et al., 2001) but amounts to no more than $0.03 \%$ of total ocean heat content per century.

We continue our examination of trends in the CMIP2+ control runs by examining longitude-averaged ocean temperature and salinity as a function of depth and latitude. We restrict ourselves to the first 80 years from each simulation in our data base for two reasons. First, 80 years was the minimum amount of control run data requested for CMIP2+ and therefore all that was provided by some groups. Second, the evaluation of the simulated mean climate in the 2004 appraisal document (and in papers related to this one) are based on 20-year climatologies computed from years 60-79 relative to the beginning of the portion of the integrations provided to us.

Figure 5 shows the anomaly of the globally and annually averaged ocean temperature as a function of depth, with respect to the first year in the time series. For the majority of models the temperature changes are very small $(<0.05 \mathrm{~K}$ in the first 80 years) over most depths, suggesting that the simulations have reached a state of quasi-equilibrium. Although the BCM Version 2, CCCma_CGCM2, and PCM reveal some drift at intermediate depths, our examination of longer portions of these runs (not shown) suggests that they too have largely achieved quasi-equilibrium by years $60-79$.

The 2004 appraisal document shows that the mean ocean temperature and salinity of the models are in general agreement with one another and with the Levitus observational data set. The Arctic Ocean is, however, an important exception. Because of this, and the fact that the Arctic Basin is uniquely isolated, results analogous to Fig. 5 are shown in Fig. 6 averaged only over the Arctic Ocean. Temperature changes are much greater: up to $\sim 0.5$ 
$\mathrm{K}$ per century at some depths in most of the models. Analogous results from the Antarctic region (Fig. 7) show considerably smaller temperature drifts in most models. While some of the variability seen in these plots can be characterized as secular trends, decadal scale variations are also evident, e.g., the intermediate waters of GFDL_R30, HadCM3 and ECHO_G.

Figures 8 and 9 are salinity anomaly analogues to the temperature Figs. 5 and 6 . In the global case (Fig. 3.7), the departure from the first year is quite small for most models (less than $0.005 \mathrm{ppt}$ ), especially below $1000 \mathrm{~m}$. In relative (percentage) terms, salinity anomalies are small compared to that of temperature. Changes in Arctic Ocean salinity are also relatively small, but intriguing nonetheless. We can make no claims concerning the realism of these basin-averaged salinity variations.

In Fig. 10 we take a cursory look at the stability of sea ice extent in several of the CMIP2+ models. The Northern and Southern Hemisphere plots depict 5-year running means of percentage changes in the total sea ice surface area with respect to the 80 -year time mean (the same 80 years shown in the temperature and salinity plots above). None of the models exhibit changes of more than $15 \%$ in total surface area during the 80 -year period, and at the end of this period all of them are within $5 \%$ of the 80 -year time mean. Not all of the models are shown because of problems in the data (or lack thereof) in some. For three of the four models shown, the simulated decadal variations of $\sim 5 \%$ are consistent with observed decadal variations (in each hemisphere) of $\sim 0.5 \times 10^{6} \mathrm{~km}^{2}$ superimposed on a mean of $\sim 10 \times 10^{6} \mathrm{~km}^{2}$ for the last two decades of the $20^{\text {th }}$ century (Cavalieri et al. 1997). The observations also include a secular decrease of $\sim 3 \%$ per decade in Arctic sea ice, perhaps due to anthropogenic global warming, which is not evident in any of the model simulations, as expected for control runs.

We must reiterate that control run output from the models used here comes from different time segments (see Table 1). Thus, conclusions concerning the relative stability of these models should not be drawn from the results of this section.

\section{Summary}

The typical first application of a new GCM is a long control run simulation in which climate forcing factors (from solar brightness, atmospheric carbon dioxide, etc.) are held constant. Traditionally, one compares long-term means from control run output with observations in the hope of obtaining close agreement - as we do in the bulk of the 2004 appraisal document. In the real world, however, climate forcing changes over time. Such changes include anthropogenic increases in both aerosols and carbon dioxide and other greenhouse gases, as well as natural variations in the Sun's output, volcanic eruptions, and many other quantities. Thus a well-behaved model control run should exhibit smaller than observed trends of surface temperature and other climatic variables. Quite the opposite situation prevailed in the early days of climate modeling. Coupled oceanatmosphere GCM simulations drifted relatively quickly and steadily unless constrained by nonphysical flux adjustments (and in some cases did so even with flux adjustments). In recent years the situation has improved dramatically. This improvement was 
documented in the most recent IPCC assessment report and is confirmed by the results given above. Although most of the CMIP2+ models employ flux adjustments, both the flux-adjusted and the non-flux-adjusted models exhibit acceptably small "climate drift" for century-scale simulations.

As noted in the CMIP2 overview, small rates of climate drift at the surface do not rule out the existence of problematic long-term drift in the deep ocean, which could threaten the viability of model simulations carried out for much longer than a century. The CMIP2+ ocean trend results, however, give at least preliminary cause for optimism in this regard. With the exception of the Arctic basin, deep ocean temperature and salinity trends are quite small over 80 years or more. The fact that several of the CMIP2+ models have been integrated for 1000 simulated years without egregious problems (e.g., Kiehl and Gent 2004) further attests the stability of modern coupled climate models, even in the absence of flux adjustments.

A final caveat is appropriate in conclusion. We have discussed models of the so-called physical climate system, including atmosphere, oceans, and sea ice, but not including biogeochemical processes such as the carbon cycle. In such models atmospheric composition (e.g., carbon dioxide amount) is specified as an input variable. Models of the more complete "Earth system" in which atmospheric composition is determined from emission rates may exhibit their own, potentially more troublesome secular climate drift. 


\section{Acknowledgments}

We are grateful to Ronald J. Stouffer for his careful reading and comments on this manuscript, and of course to the groups that contributed output for CMIP and the PCMDI's appraisal of climate models. This work was supported under the auspices of the Office of Science, U.S. Dept. of Energy, Office of Science, at the University of California Lawrence Livermore National Laboratory under Contract W-7405-Eng-48. 


\section{References}

AchutaRao, K., C. Covey, C. Doutriaux, M. Fiorino, P. Gleckler, T. Phillips, K. Sperber, K. Taylor and D. Bader, 2004: An Appraisal of Coupled Climate Simulations, PCMDI Report No. 71, UCRL-TR-202550, Lawrence Livermore National Laboratory. Available on the Web at http://www-pcmdi.llnl.gov.

Barnett, T. P., D. W. Pierce, and R. Schnur (2001): Detection of anthropogenic climate change in the world's oceans, Science, 292, 270-274.

Bleck, R., C. Rooth, D. Hu, and L.T. Smith, 1992: Salinity-driven thermocline transients in a wind- and thermohaline-forced isopycnic coordinate model of the North Atlantic. $J$. Phys. Oceanogr., 22, 1486-1505..

Bryan, F. O., 1998: Climate drift in a multicentury integration of the NCAR Climate System Model, J. Climate, 11, 1455-1471.

Cavalieri, D.J., P. Gloersen, C.L. Parkinson, J.C. Comiso and H.J. Zwally, 1997:

Observed hemispheric asymmetry in global sea ice changes, Science, 278, 1104-1106.

Collins, W.D., J.J. Hack, B.A. Boville, P.J. Rasch, D.L. Williamson, J.T. Kiehl, B. Briegleb, and J.R. McCaa, 2003: Description of the NCAR Community Atmosphere Model (CAM2). Accessible online at http://www.ccsm.ucar.edu/models/atm-cam/ index.html.

Covey, C., K.M. AchutaRao, U. Cubasch, P. Jones, S.J. Lambert, M.E. Mann, T.J. Phillips and K.E. Taylor, 2003: An overview of results from the Coupled Model Intercomparison Project, Glob. and Planet. Change, 37, 103-133.

Cox, M.D., 1984: A primitive equation, three-dimensional model of the ocean. GFDL Ocean Group Technical Report No. 1, Geophysical Fluid Dynamics Laboratory, Princeton, New Jersey, 141 pp.

Cullen, M.J.P., 1993: The unified forecast/climate model. Meteor. Mag., 122, 81-94.

Delworth, T.L., R.S. Stouffer, K.W. Dixon, M.J. Spelman, T.R. Knutson, A.J. Broccoli, P.J. Kushner, and R.T. Wetherald, 2002: Simulation of climate variability and change by the GFDL R30 coupled model. Climate Dyn., 19, 555-574.

Deque, M., C. Dreveton, A. Braun, and D. Cariolle, 1994: The ARPEGE/IFS atmosphere model: A contribution to the French community climate modeling. Climate Dyn., 10, 249-266.

Flato, G.M., G.J. Boer, W.G. Lee, N.A. McFarlane, D. Ramsden, M.C. Reader, and A.J. Weaver, 2000: The Canadian Centre for Climate Modelling and Analysis global coupled model and its climate. Climate Dyn., 16, 451-467. 
Furevik, T., B. M. Bentsen, H. Drange, I.K.T. Kindem, N.G. Kvamstø, and A. Sorteberg, 2003: Description and validation of the Bergen Climate Model: ARPEGE coupled with MICOM. Climate Dyn., 21, 27-51.

Gates, W. L., and Coauthors, 1996: Climate models - evaluation. In Climate Climate 1995: The Science of Climate Change, J. T. Houghton et al. (eds.), Cambridge University Press, 229-284.

Gates, W.L., and Coauthors, 1999: An overview of results from the Atmospheric Model Intercomparison Project (AMIP1). Bull. Amer. Meteorol. Soc., 80, 29-55.

Gordon, C., C. Cooper, C.A. Senior, H.T. Banks, J.M. Gregory, T.C. Johns, J.F.B. Mitchell, and R.A. Wood, 2000: The simulation of SST, sea ice extents and ocean heat transports in a version of the Hadley Centre coupled model without flux adjustments. Climate Dyn., 16, 147-168.

Gordon, H.B., and S.P. O'Farrell, 1997: Transient climate change in the CSIRO coupled model with dynamic sea ice. Mon. Wea. Rev., 125, 875-907.

Hirst, A.C., S.P. O'Farrell, and H.B. Gordon, 2000: Comparison of a coupled oceanatmosphere model with and without oceanic eddy-induced advection. 1. Ocean spin-up and control integrations. J. Climate, 13, 139-163.

Jenkins, G. M., and D. G. Watts, 1968: Spectral Analysis and its Applications, HoldenDay, pp. 310-311.

Johns, T.C., R.E. Carnell, J.F. Crossley, J.M. Gregory, J.F.B. Mitchell, C.A. Senior, S.F.B. Tett, and R.A. Wood, 1997: The second Hadley Centre coupled ocean-atmosphere GCM: Model description, spinup and validation. Climate Dyn., 13, 103-134.

Jones, P. D., M. New, D. E. Parker, S. Martin, and I. G. Rigor, 1999: Surface air temperature and its changes over the past 150 years. Rev. Geophys., 37, 173-199.

Kiehl, J. T., and P. R. Gent, 2004: The Community Climate System Model, Version Two, J. Climate (submitted).

Kiehl, J.T., J.J. Hack, G. Bonan, B.A. Boville, D. Williamson, and P. Rasch, 1998: The National Center for Atmospheric Research Community Climate Model: CCM3. J. Climate, 11, 1131-1149.

Levitus, S., 1982: Climatological atlas of the world's oceans. NOAA Professional Paper $13,173 \mathrm{pp}$.

Levitus, S. and T.P. Boyer, 1994: World ocean atlas 1994, Vol. 4: Temperature. NOAA/NESDIS E/OC21, U.S. Department of Commerce, Washington, D.C., 117 pp.

Levitus, S., R. Burgett, and T.P. Boyer, 1995: World ocean atlas 1994, Vol. 3: Salinity. NOAA/NESDIS E/OC21, U.S. Department of Commerce, Washington, D.C., 99 pp. 
Maltrud, M.E., R.D. Smith, A.J. Semtner, and R.C. Malone, 1998: Global eddy-resolving ocean simulations driven by 1985-1995 atmospheric winds. J. Geophys. Res., 103, $30,825-30,853$.

McAvaney, B. J., and Coauthors, 2001: Model Evaluation. In Climate Change 2001: The Scientific Basis, J. T. Houghton, et al., Eds., Cambridge University Press, 471-521.

McFarlane, N.A., G.J. Boer, J.-P. Blanchet, and M. Lazare, 1992: The Canadian Climate Centre second-generation general circulation model and its equilibrium climate. $J$.

Climate, 5, 1013-1044.

McGregor, J.L., H.B. Gordon, I.G. Watterson, M.R. Dix, and L.D. Rotstayn, 1993: The CSIRO 9-level atmospheric general circulation model. CSIRO Divsion of Atmospheric Research Technical Paper No. 26, CSIRO, Mordialloc, Australia, 89 pp.

Min, S-K., S. Legutke, A. Hense, and W-T. Kwon, 2004: Climatology and internal variability in a 1000-year control simulation with the coupled climate model ECHO-G. M\&D Technical Report No. 2, Modelle \& Daten, Hamburg, Germany, 67 pp. Accessible online at http://mad.zmaw.de/Pingo/reports/TeReport Web02.pdf . Also submitted to Climate Dynamics.

Noda, A., S. Yukimoto, S. Maeda, T. Uchiyama, K. Shibata, and S. Yamaki, 2001: A new Meteorological Research Institute coupled GCM (MRI-CGCM2)—Transient response to greenhouse gas and aerosol scenarios. CGER's Supercomputer Monograph Report Vol. 7, Center for Global Environmental Research, National Institute for Environmental Studies, Ibaraki 305-0053, Japan, 63 pp.

Oberhuber, J. M., 1993: Simulation of the Atlantic circulation with a coupled sea-icemixed layer-isopycnical general circulation model. Part I: model description. J. Phys. Oceanogr., 23, 808-829.

Pacanowski, R.C., K. Dixon, and A. Rosati, 1993: The GFDL modular ocean model users guide, version 1.0. GFDL Ocean Group Technical Report No. 2, Geophysical Fluid Dynamics Laboratory, Princeton, New Jersey.

Pope, V.D., M.L. Gallani, P.R. Rowntree, and R.A. Stratton, 2000: The impact of new physical parametrizations in the Hadley Centre climate model: HadAM3. Climate Dyn., $16,123-146$.

Rayner, N.A., D. E. Parker, E. B. Horton, C. K. Folland, L. V. Alexander, D. P. Rowell, E. C. Kent, and A. Kaplan, 2003: "Global analyses of sea surface temperature, sea ice, and night marine air temperature since the late nineteenth century". Journal of Geophysical Research, Vol. 108, No. D14, 4407, doi:10.1029/2002JD002670, 2003

Roeckner, E., J.M. Oberhuber, A Bacher, M. Christoph, and I. Kirchner, 1996a: ENSO variability and atmospheric response in a global coupled atmosphere-ocean GCM. Climate Dyn., 12, 737-754. 
Roeckner, E., K. Arpe, L. Bengtsson, M. Christoph, M. Claussen, L. Dümenil, M. Esch, M. Giorgetta, U. Schlese, and U. Schulzweida, 1996b: The atmospheric general circulation model ECHAM4: Model description and simulation of present-day climate. MPI Report No. 218, Max-Planck-Institut für Meteorologie, Hamburg, Germany, 90 pp.

Smith, R., and P. Gent (eds.), 2002: Reference manual for the Parallel Ocean Program (POP): Ocean component of the Community Climate System Model (CCSM2.0). Accessible online at http://www.cgd.ucar.edu/csm/models/ccsm2.0.1/pop/doc/sci_ref_manual.pdf.

Washington, W.M., J.M. Weatherly, G.A. Meehl, A.J. Semtner, Jr., T.W. Bettge, A.P. Craig, W.G. Strand, J. Arblaster, V.B. Wayland, R. James, and Y. Zhang, 2000: Parallel Climate Model (PCM) control and transient simulations. Climate Dyn., 16, 755-774.

Wolff, J-O., E. Maier-Reimer, and S. Lebutke, 1997: The Hamburg ocean primitive equation model. DKRZ Technical Report No. 13, Deutsches KlimaRechenZentrum, Hamburg, Germany, 100 pp. Also at http://www.mad.zmaw.de/

Pingo/reports/ReportNo.13.pdf.

Yukimoto, S., A. Noda, A. Kitoh, M. Sugi, Y. Kitamura, M. Hosaka, K. Shibata, S. Maeda, and T. Uchiyama, 2001: The new Meteorological Research Institute global ocean-atmosphere coupled GCM (MRI-CGCM2)--Model climate and variability. Papers Meteor. and Geophys., 51, 47-88.

Yukimoto, S., and A. Noda, 2003: Improvements of the Meteorological Research Institute global ocean-atmosphere coupled GCM (MRI-GCM2) and its climate sensitivity. CGER's Supercomputing Activity Report, National Institute for Environmental Studies, Tsukuba, Japan. 
Table 1: Features of coupled ocean-atmosphere general circulation models listed alphabetically by model acronym along with the approximate year of the simulation ("vintage") and key references. Also listed are sponsoring institutions and their national affiliations, the horizontal and vertical resolution of the model atmosphere and ocean, the types of coupled surface flux adjustments employed (if any) with a relevant reference, the duration of the coupled ocean-atmosphere spin-up prior to the start of the control simulation, and the years of the control run that were provided for archiving at PCMDI.

\begin{tabular}{|c|c|c|c|c|c|}
\hline $\begin{array}{l}\text { Model/Vintage } \\
\text { Key References }\end{array}$ & Sponsor, Country & $\begin{array}{l}\text { *Resolution: } \\
\text { Atmosphere/Ocn }\end{array}$ & $\begin{array}{l}\text { Flux Adjustments, } \\
\text { Reference }\end{array}$ & $\begin{array}{l}\text { Coupled } \\
\text { Spin-up } \\
\text { Duration }\end{array}$ & $\begin{array}{l}\text { Archived } \\
\text { Control } \\
\text { Years }\end{array}$ \\
\hline $\begin{array}{l}\text { BCM/2002 } \\
\text { Deque et al. } 1994, \\
\text { Bleck et al. } 1992\end{array}$ & $\begin{array}{l}\text { University of Bergen (UB), } \\
\text { Norway }\end{array}$ & $\begin{array}{l}\mathrm{T} 63\left(1.9^{\circ} \times 1.9^{\circ}\right) \mathrm{L} 31 / \\
0.8-2.4^{\circ} \times 2.4^{\circ} \mathrm{L} 24\end{array}$ & $\begin{array}{l}\text { Heat, Fresh Water } \\
\text { Furevik et al. } 2003\end{array}$ & 25 Years & $1-300$ \\
\hline $\begin{array}{l}\text { CCCma_CGCM2/2001 } \\
\text { McFarlane et al.1992, } \\
\text { Pacanowski et al. } 1993\end{array}$ & $\begin{array}{l}\text { Canadian Centre for Climate } \\
\text { Modelling \&Analysis (CCCma), } \\
\text { Canada }\end{array}$ & $\begin{array}{l}\mathrm{T} 32\left(3.7^{\circ} \times 3.7^{\circ}\right) \mathrm{L} 10 / \\
1.9^{\circ} \times 1.9^{\circ} \mathrm{L} 29\end{array}$ & $\begin{array}{l}\text { Heat, Fresh Water } \\
\text { Flato et al. } 2000\end{array}$ & 50 Years & $51-130$ \\
\hline $\begin{array}{l}\text { CCSM2.0/2002 } \\
\text { Collins et al. } 2003 \text {, } \\
\text { Smith\&Gent } 2002\end{array}$ & $\begin{array}{l}\text { National Center for Atmospheric } \\
\text { Research (NCAR), USA }\end{array}$ & $\begin{array}{l}\mathrm{T} 42\left(2.8^{\circ} \times 2.8^{\circ}\right) \mathrm{L} 26 / \\
0.3-1.0^{\circ} \times 1.0^{\circ} \mathrm{L} 40\end{array}$ & $\begin{array}{l}\text { None } \\
\text { Kiehl \& Gent } 2004\end{array}$ & 350 Years & $1-650$ \\
\hline $\begin{array}{l}\text { CSIRO_Mk2/1997 } \\
\text { McGregor et al. 1993, } \\
\text { Hirst et al. } 2000\end{array}$ & $\begin{array}{l}\text { Commonwealth Scientific \& } \\
\text { Industrial Research Organization } \\
\text { (CSIRO), Australia }\end{array}$ & $\begin{array}{l}\mathrm{R} 21\left(3.2^{\circ} \times 5.6^{\circ}\right) \mathrm{L} 9 / \\
3.2^{\circ} \times 5.6^{\circ} \mathrm{L} 21\end{array}$ & $\begin{array}{l}\text { Heat, Fresh Water, } \\
\text { Momentum } \\
\text { Gordon \& O'Farrell } 1997\end{array}$ & 105 Years & $351-450$ \\
\hline $\begin{array}{l}\text { ECHAM4_OPYC3/1996 } \\
\text { Roeckner et al 1996b, } \\
\text { Oberhuber } 1993\end{array}$ & $\begin{array}{l}\text { Max Planck Institut fur } \\
\text { Meteorologie (MPI), Germany }\end{array}$ & $\begin{array}{l}\text { T42 }\left(2.8^{\circ} \times 2.8^{\circ}\right) \mathrm{L} 19 / \\
0.5-2.8^{\circ} \times 2.8^{\circ} \mathrm{L} 11\end{array}$ & $\begin{array}{l}\text { Heat, Fresh Water } \\
\text { Roeckner et al 1996a }\end{array}$ & 100 Years & $150-299$ \\
\hline $\begin{array}{l}\text { ECHO-G/1999, } \\
\text { Roeckner et al. } 1996 \text { a, } \\
\text { Wolff et al. } 1997\end{array}$ & $\begin{array}{l}\text { Model \& Data Group (M\&D), } \\
\text { Germany }\end{array}$ & $\begin{array}{l}\text { T30 }\left(3.9^{\circ} \times 3.9^{\circ}\right) \mathrm{L} 19 / \\
0.5-2.8^{\circ} \times 2.8^{\circ} \mathrm{L} 20\end{array}$ & $\begin{array}{l}\text { Heat, Fresh Water } \\
\text { Min et al. } 2004\end{array}$ & 155 Years & $310-409$ \\
\hline
\end{tabular}




\begin{tabular}{|c|c|c|c|c|c|}
\hline $\begin{array}{l}\text { Model/Vintage } \\
\text { Key References }\end{array}$ & Sponsor, Country & $\begin{array}{l}\text { *Resolution: } \\
\text { Atmosphere/Ocn }\end{array}$ & $\begin{array}{l}\text { Flux Adjustments, } \\
\text { Reference }\end{array}$ & $\begin{array}{l}\text { Coupled } \\
\text { Spin-up } \\
\text { Duration }\end{array}$ & $\begin{array}{l}\text { Archived } \\
\text { Control } \\
\text { Years }\end{array}$ \\
\hline $\begin{array}{l}\text { GFDL_R30_c/1996 } \\
\text { Delworth et al. 2002, } \\
\text { Pacanowski et al. } 1993\end{array}$ & $\begin{array}{l}\text { Geophysical Fluid Dynamics } \\
\text { Laboratory (GFDL), USA }\end{array}$ & $\begin{array}{l}\mathrm{R} 30\left(2.3^{\circ} \times 3.8^{\circ}\right) \mathrm{L} 14 / \\
1.9^{\circ} \mathrm{x} 2.3^{\circ} \mathrm{L} 18\end{array}$ & $\begin{array}{l}\text { Heat, Fresh Water } \\
\text { Delworth et al. } 2002\end{array}$ & None & $1-300$ \\
\hline $\begin{array}{l}\text { HadCM2/1995 } \\
\text { Cullen 1993, } \\
\text { Cox } 1984\end{array}$ & $\begin{array}{l}\text { Meteorological Office (MO), } \\
\text { UK }\end{array}$ & $\begin{array}{l}2.5^{\circ} \times 3.8^{\circ} \mathrm{L} 19 / \\
2.5^{\circ} \times 3.8^{\circ} \mathrm{L} 20\end{array}$ & $\begin{array}{l}\text { Heat, Fresh Water } \\
\text { Johns et al. } 1997\end{array}$ & 510 Years & $1-80$ \\
\hline $\begin{array}{l}\text { HadCM3/1997 } \\
\text { Pope et al. } 2000, \\
\text { Gordon et al. } 2000\end{array}$ & & $\begin{array}{l}2.5^{\circ} \times 3.8^{\circ} \mathrm{L} 19 / \\
1.5^{\circ} \times 1.5^{\circ} \mathrm{L} 20\end{array}$ & $\begin{array}{l}\text { None } \\
\text { Gordon et al. } 2000\end{array}$ & 400 Years & $101-180$ \\
\hline $\begin{array}{l}\text { MRI_CGCM2.3/2002 } \\
\text { Noda et al. 2001, } \\
\text { Yukimoto et al. } 2001\end{array}$ & $\begin{array}{l}\text { Meteorological Research } \\
\text { Institute (MRI), Japan }\end{array}$ & $\begin{array}{l}\mathrm{T} 42\left(2.8^{\circ} \times 2.8^{\circ}\right) \mathrm{L} 30 / \\
0.5-2.0^{\circ} \times 2.5^{\circ} \mathrm{L} 23\end{array}$ & $\begin{array}{l}\text { Heat, Fresh Water } \\
\text { Yukimoto \& Noda } 2003\end{array}$ & 95 Years & $1-150$ \\
\hline $\begin{array}{l}\text { PCM/1999 } \\
\text { Kiehl et al. 1998, } \\
\text { Maltrud et al. } 1998\end{array}$ & $\begin{array}{l}\text { Department of Energy(DOE), } \\
\text { USA }\end{array}$ & $\begin{array}{l}\mathrm{T} 42\left(2.8^{\circ} \times 2.8^{\circ}\right) \mathrm{L} 18 / \\
0.5-.7^{\circ} \times 0.7^{\circ} \mathrm{L} 32\end{array}$ & $\begin{array}{l}\text { None } \\
\text { Washington et al. } 2000\end{array}$ & 50 Years & $1-300$ \\
\hline
\end{tabular}

\section{*Resolution: Atmosphere/Ocean}

In atmospheric models with finite-difference numerics, the horizontal resolution is expressed as the size of a model grid box in degrees latitude $x$ degrees longitude. In models employing spectral representations of atmospheric fields, the horizontal resolution is expressed as the truncation (following triangular $\mathrm{T}$, or rhomboidal $\mathrm{R}$ schemas) wave number followed by a roughly equivalent latitude $\mathrm{x}$ longitude grid spacing. For the ocean model, variable latitudinal resolution (e.g. $0.8-2.4^{\circ}$ ) is indicative of the provision for finer resolution near the Equator. Vertical resolution in both atmosphere and ocean models is expressed in terms of the number of vertical levels L. 
Table 2: SST trends for the CMIP2+ models ( $\mathrm{K}$ / century).

\begin{tabular}{llc}
\hline \multicolumn{1}{c}{ Model or observed dataset } & \multicolumn{1}{c}{$\begin{array}{c}\text { Area-averaged mean } \\
\text { over grid points }\end{array}$} & $\begin{array}{c}\text { Area-averaged RMS } \\
\text { over grid points }\end{array}$ \\
\hline Observed 1956-2001 ${ }^{\mathrm{a}}$ & 0.598 & 1.07 \\
BCM_version1 & 0.157 & 0.14 \\
CCCma_CGCM2 & 0.397 & 0.72 \\
CCSM2.0 & -0.031 & 0.15 \\
CSIRO_Mk2 & -0.008 & 0.25 \\
ECHAM4_OPYC3 & 0.081 & 0.87 \\
ECHO-G & 0.114 & 0.61 \\
GFDL_R30_c & -0.029 & 0.36 \\
HadCM2 & -0.014 & 0.46 \\
HadCM3 & 0.017 & 0.80 \\
MRICGCM2.3 & 0.017 & 0.11 \\
PCM & 0.036 & 0.28 \\
a $^{\text {a }}$ As compiled for AMIP boundary conditions. & & \\
${ }^{b}$ Not flux-adjusted. & &
\end{tabular}




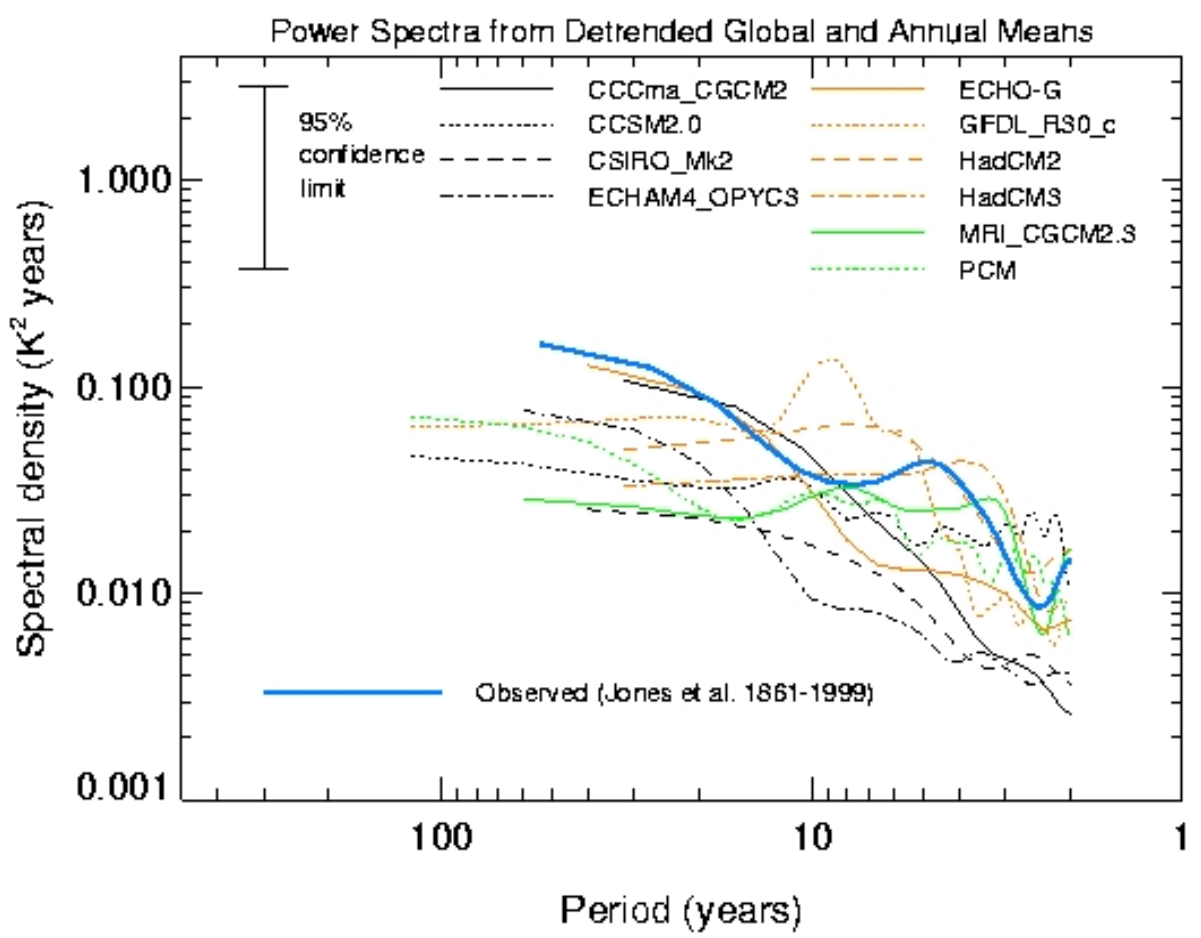

Fig. 1. Power spectra of detrended globally and annually averaged surface air temperature simulated by CMIP2+ models and observed by Jones / IPCC. The curves are scaled so that the areas under them (if plotted linearly) equal the total variances about the mean of the detrended time series. The $95 \%$ confidence interval-based only on uncertainties due to finite sample size-is the same for all cases with the logarithmic scales used in this graphic. The models exhibit global variability that is typically less than observed, as expected for control run simulations. 

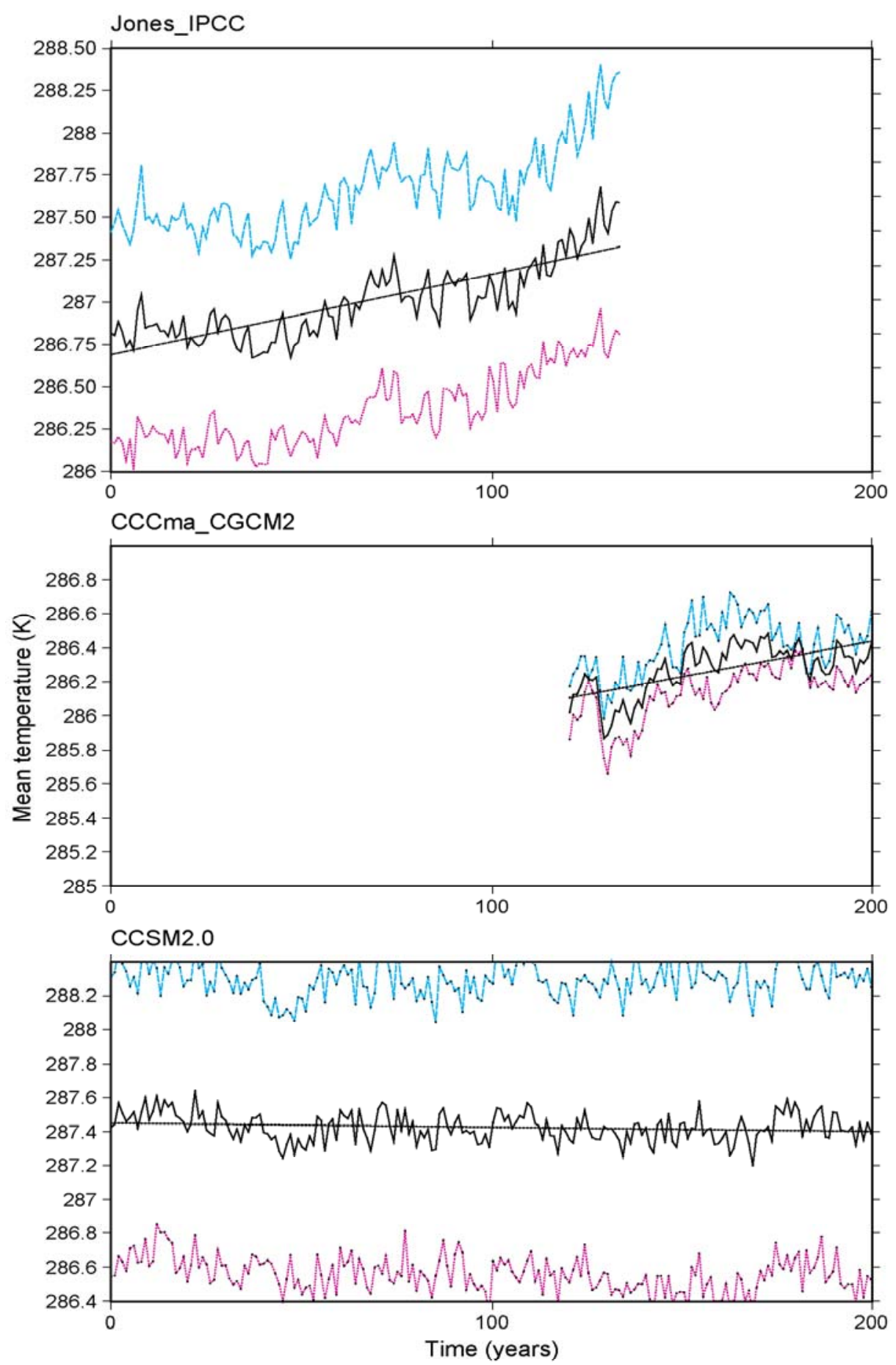

Fig. 2. Time series of annual mean surface air temperature from the last 200 years of CMIP2+ control runs integrations and observed by Jones / IPCC. Blue curves are Northern Hemisphere means, pink curves are Southern Hemisphere means, and black curves are global means. Black straight lines are linear least-square fits to global means. The models typically exhibit smaller trends than observed, as expected for control run simulations. 


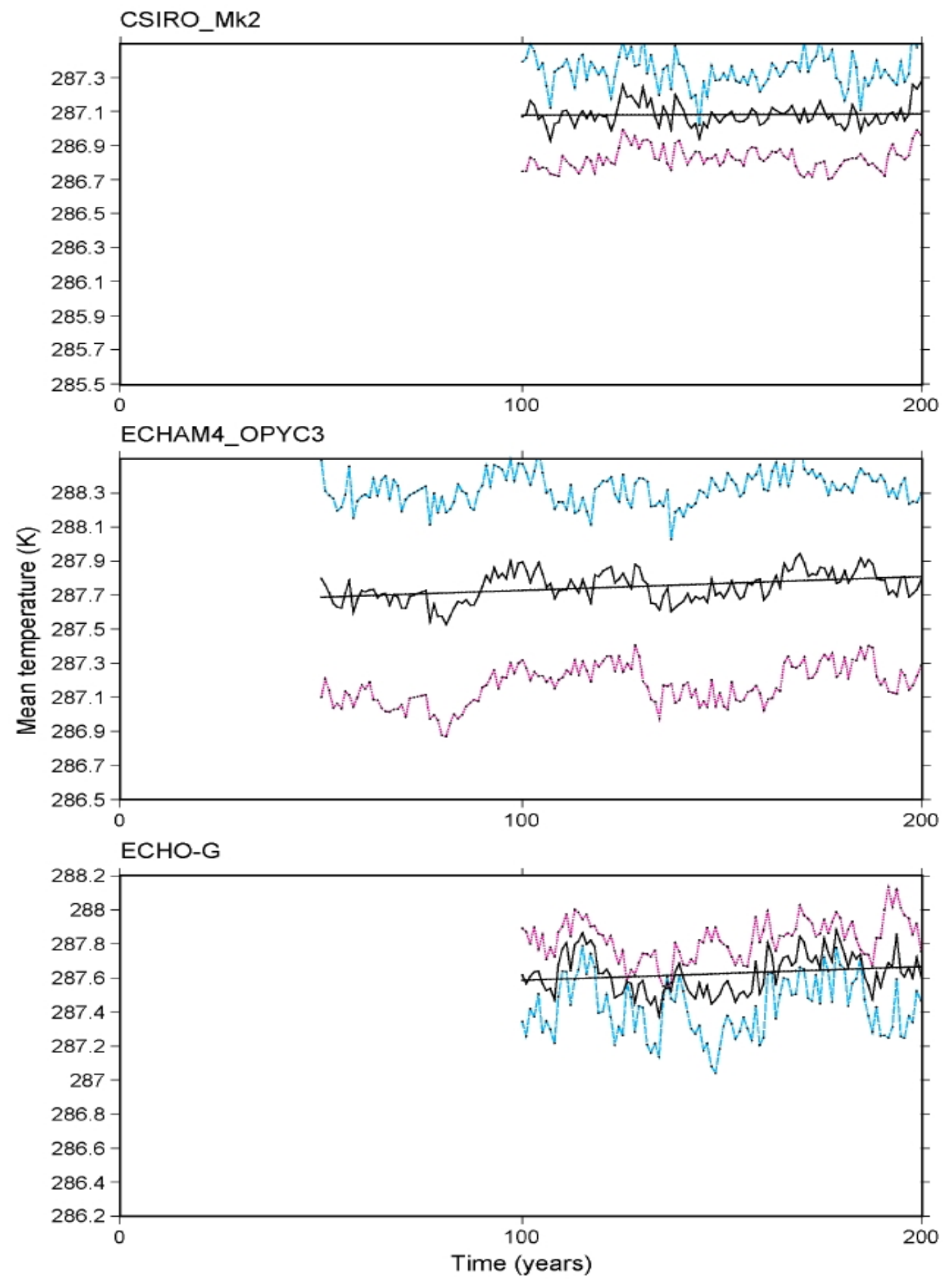

Fig. 2 (cont.). Time series of annual mean surface air temperature from the last 200 years of CMIP2+ control runs integrations and observed by Jones / IPCC. Blue curves are Northern Hemisphere means, pink curves are Southern Hemisphere means, and black curves are global means. Black straight lines are linear least square fits to global means. The models typically exhibit smaller trends than observed, as expected for control run simulations. 


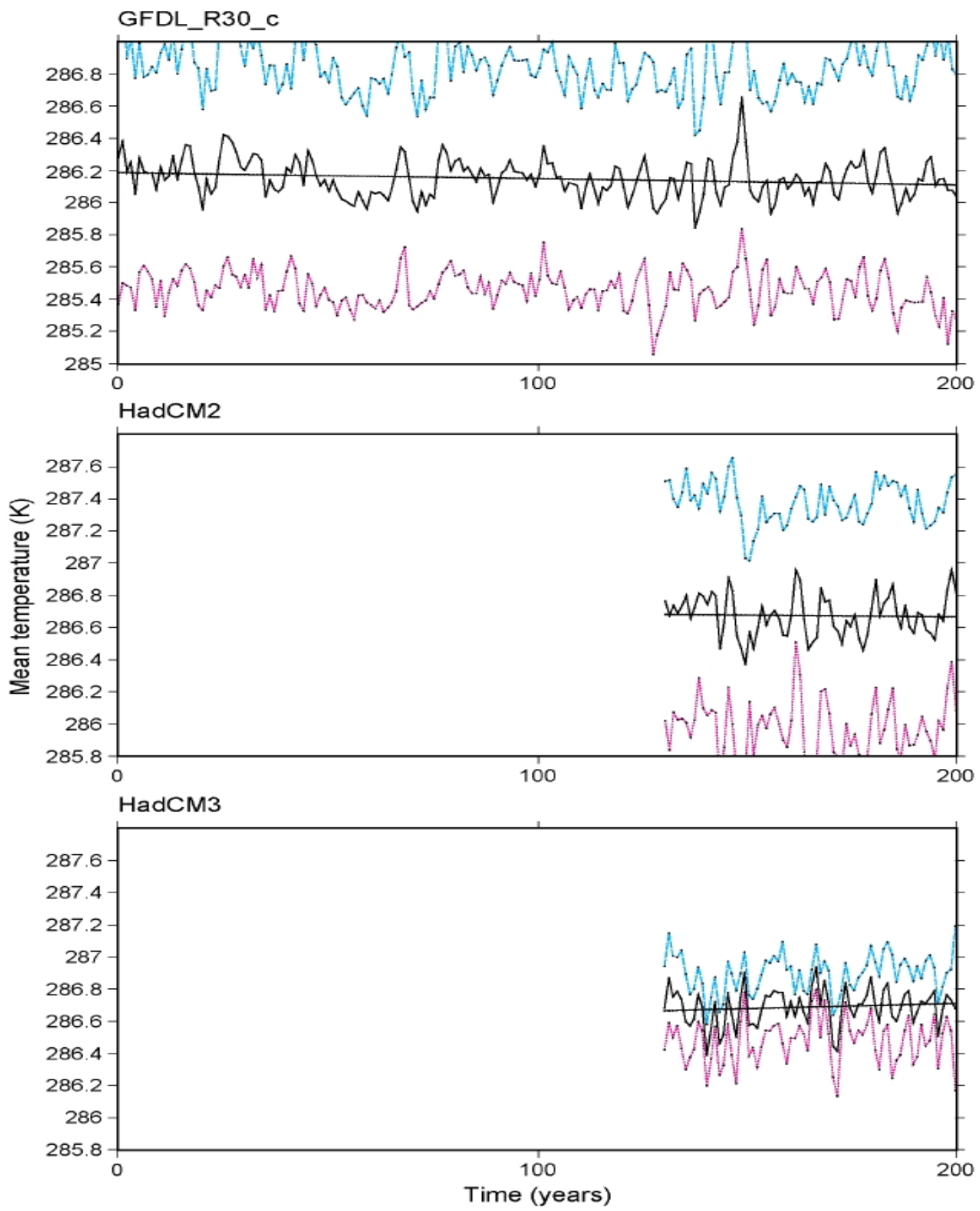

Fig. 2 (cont.). Time series of annual mean surface air temperature from the last 200 years of CMIP2+ control runs integrations and observed by Jones / IPCC. Blue curves are Northern Hemisphere means, pink curves are Southern Hemisphere means, and black curves are global means. Black straight lines are linear least-square fits to global means. The models typically exhibit smaller trends than observed, as expected for control run simulations. 


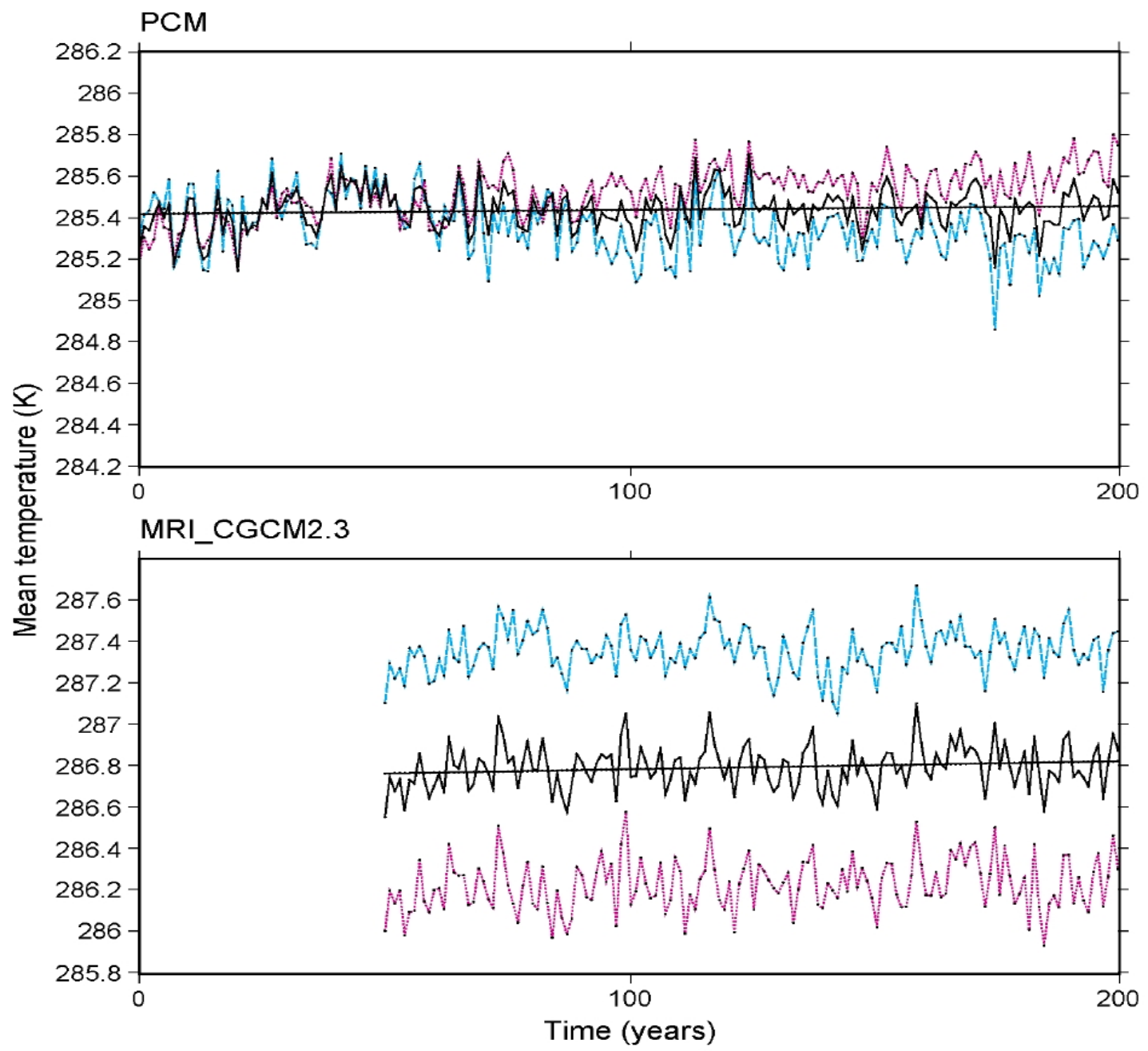

Fig. 2 (cont.). Time series of annual mean surface air temperature from the last 200 years of CMIP2+ control runs integrations and observed by Jones / IPCC. Blue curves are Northern Hemisphere means, pink curves are Southern Hemisphere means, and black curves are global means. Black straight lines are linear least-square fits to global means. The models typically exhibit smaller trends than observed, as expected for control run simulations. 

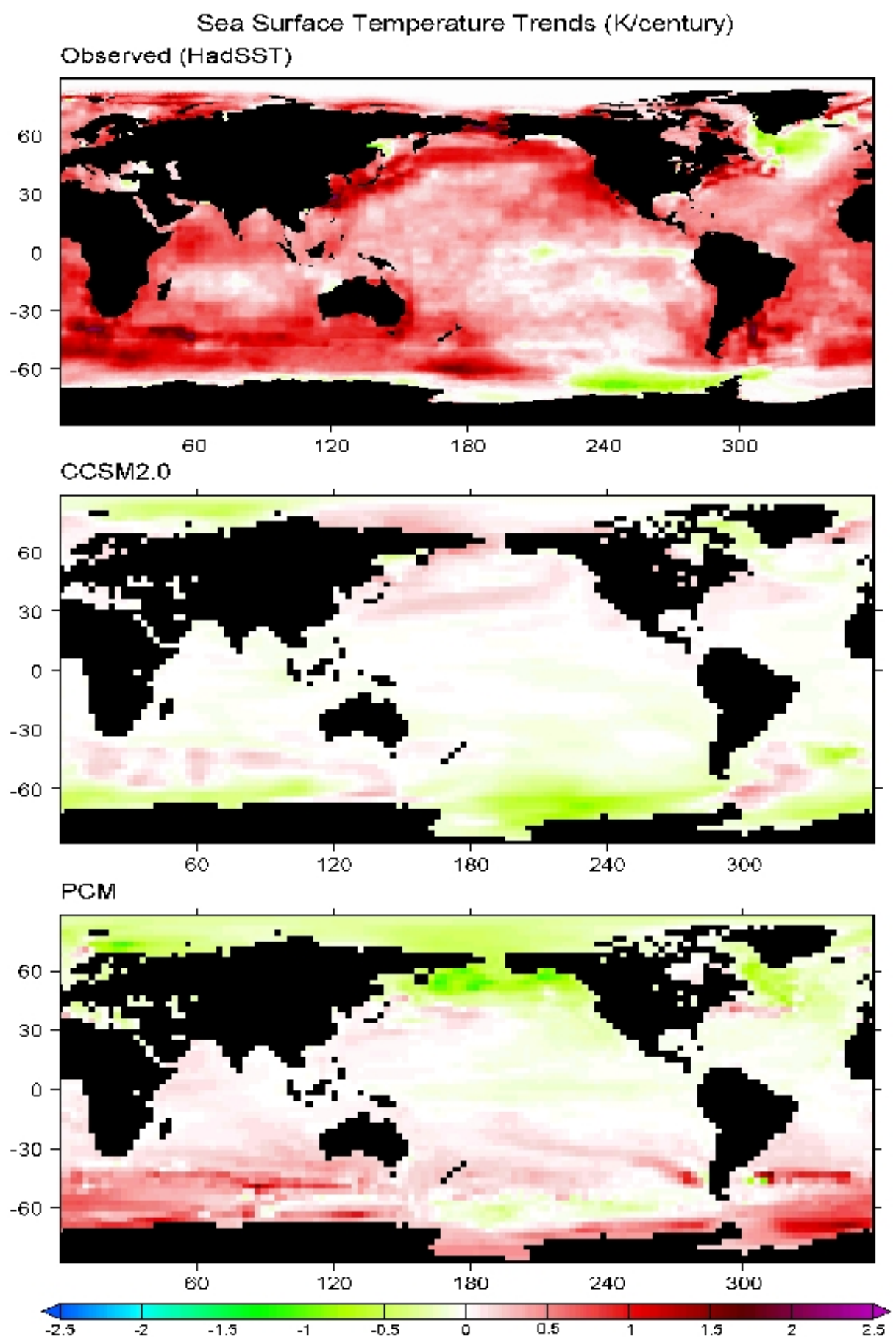

Fig. 3. Sea surface temperature trends observed for the period 1898-1997 (HadSST database) and simulated by two of the three CMIP2+ models that are not flux-adjusted. Results of globally averaging these trends are given in Table 2 for the results shown in this figure and for all other CMIP2+ models. All the models exhibit trends that are considerably smaller than observed, as expected for control run simulations. 


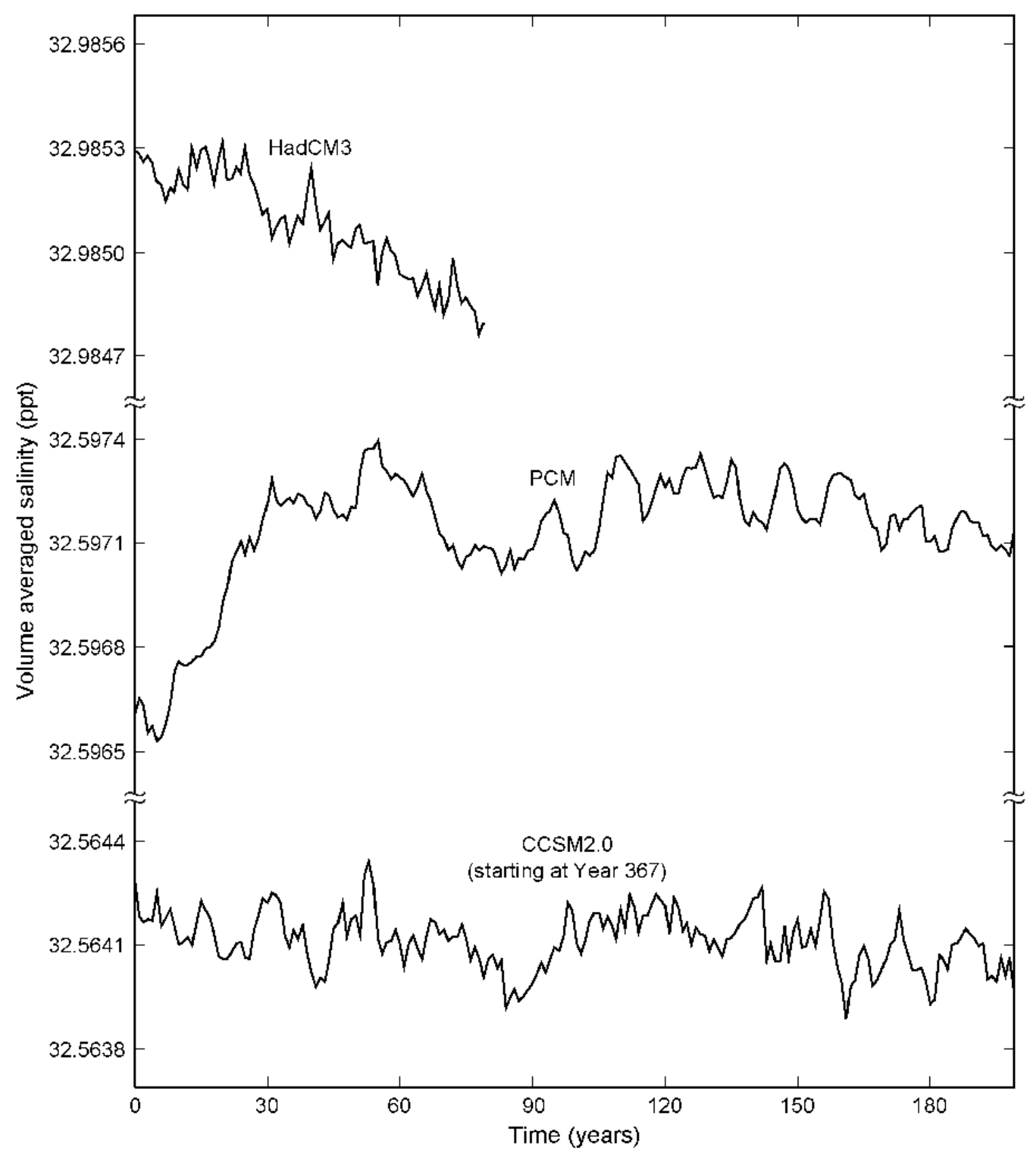

Fig. 4. Average salinity over total ocean volume for the three CMIP2+ models that were not flux-adjusted. 

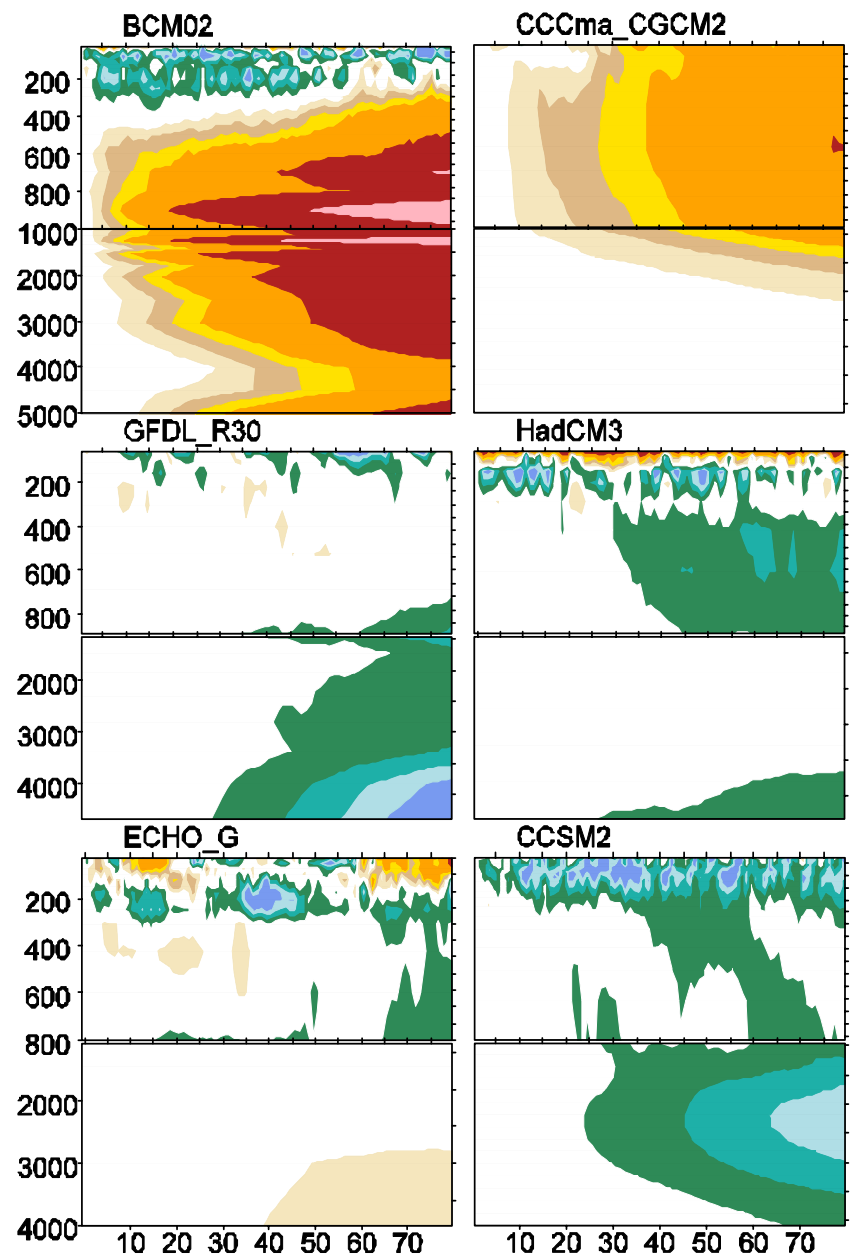

CSIRO Mk2
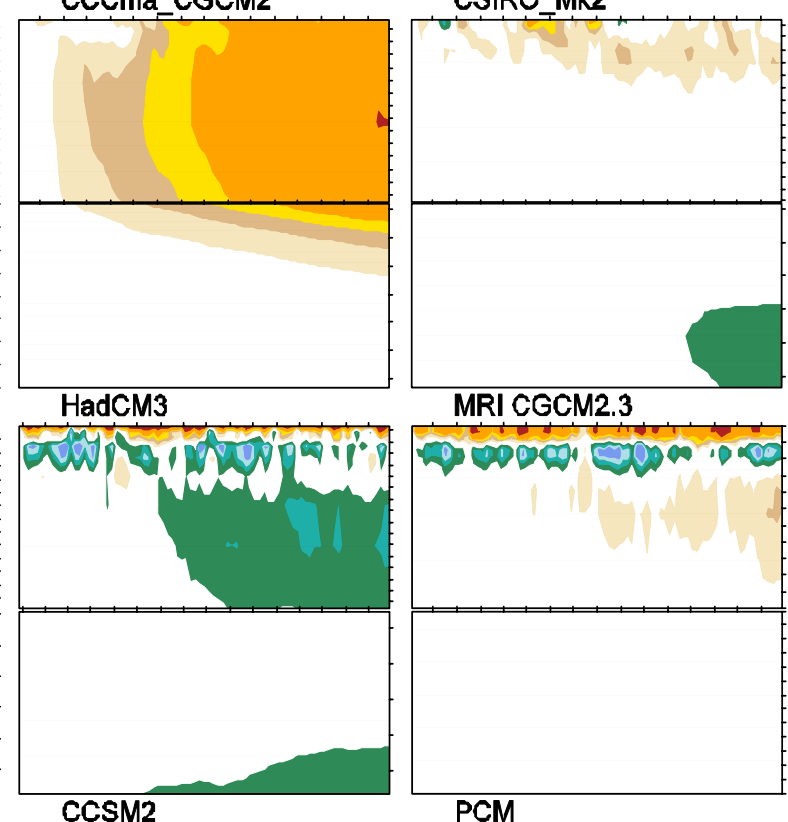

MRI CGCM2.3
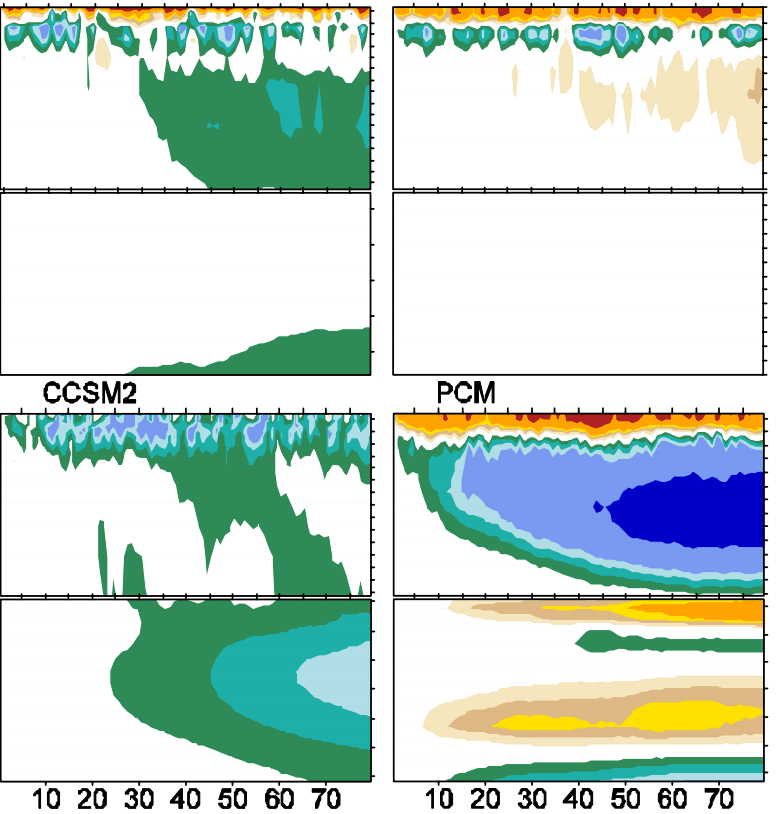

Global Ocean

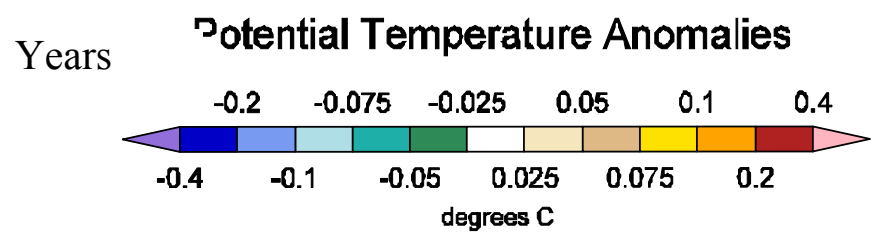

Fig. 5. Deviation of the globally and annually averaged ocean temperature from the first year (of data archived at PCMDI) as a function of depth (degrees K). The three models that are most suggestive of trends (BCM02, CCCma and PCM) are found to approach quasi-equilibrium later in the integrations (not shown). In each case, years 60-79 are found to be periods of relative stability. 

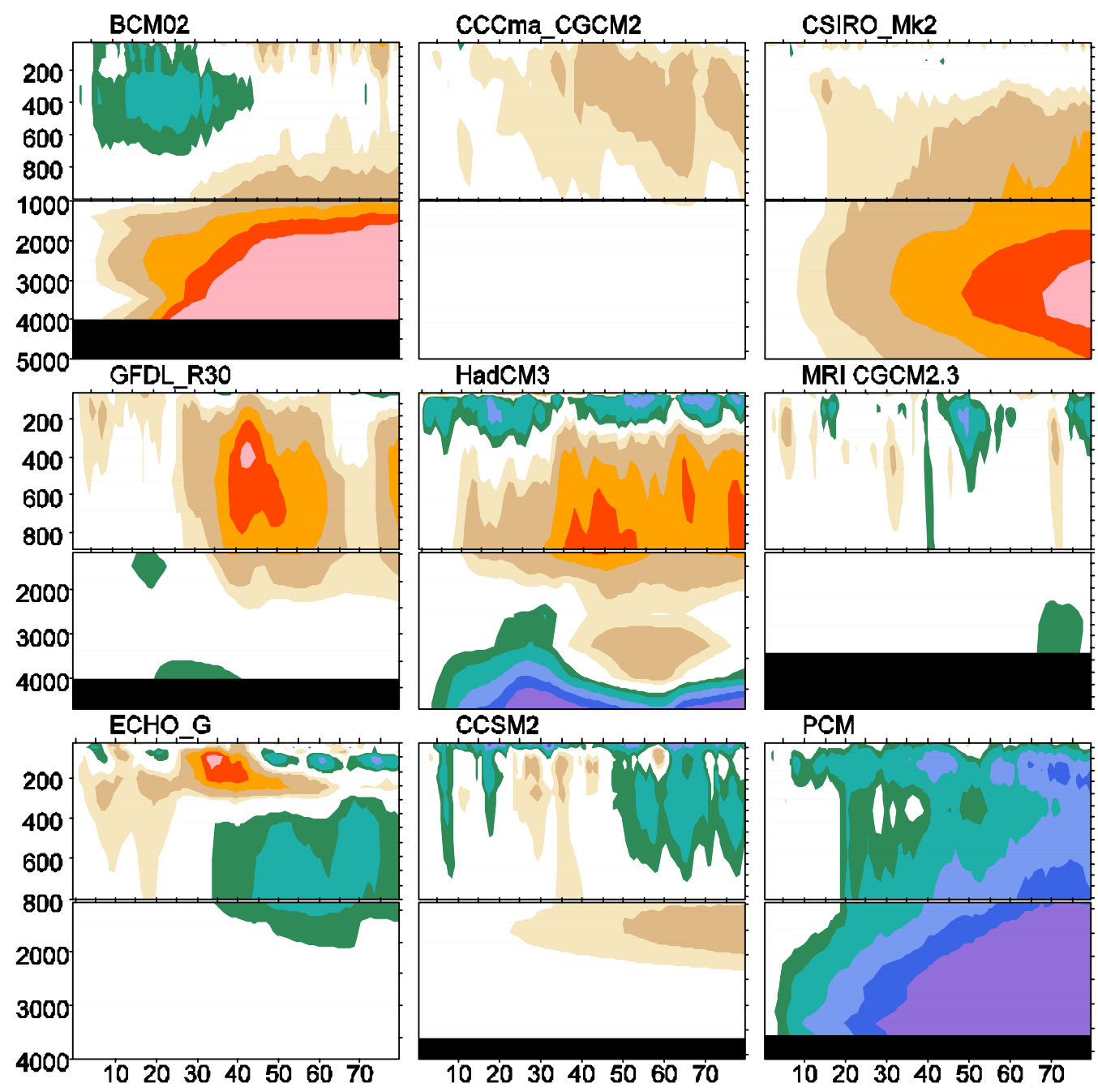

10203040506070

$10 \quad 20 \quad 30 \quad 40 \quad 50 \quad 60 \quad 70$

\section{Arctic Ocean}

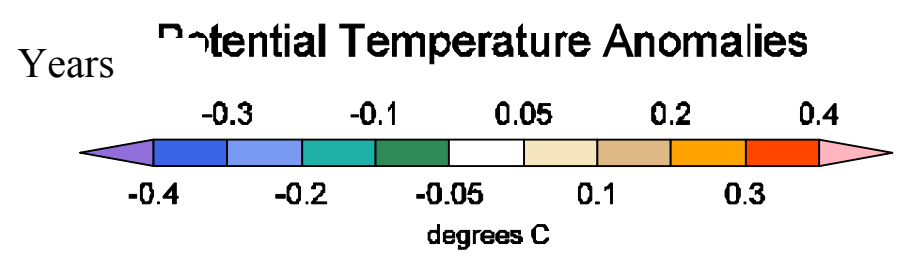

Fig. 6. Deviation of the Arctic Basin annual mean temperature from the first year (of data archived at PCMDI) as a function of depth (degrees K). 


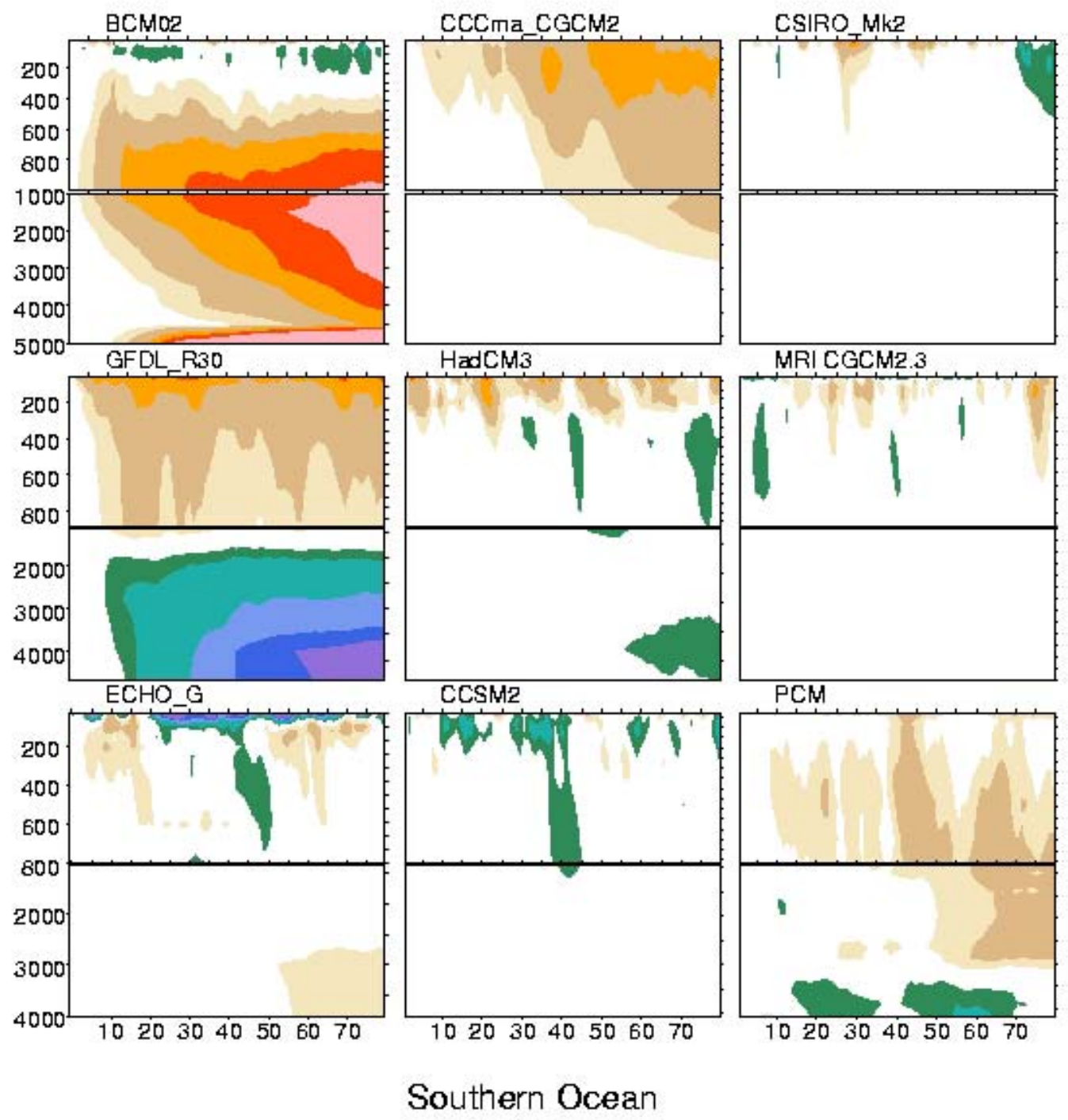

Potential Temperature Anomalies

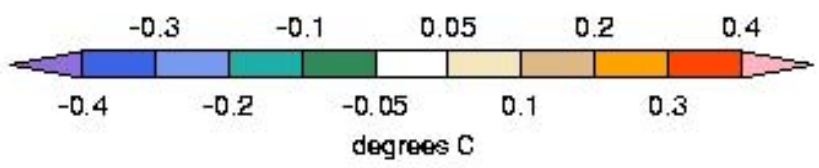

Fig. 7. Deviation of the Antarctic Basin annual mean temperature from the first year (of data archived at PCMDI) as a function of depth (degrees K) 

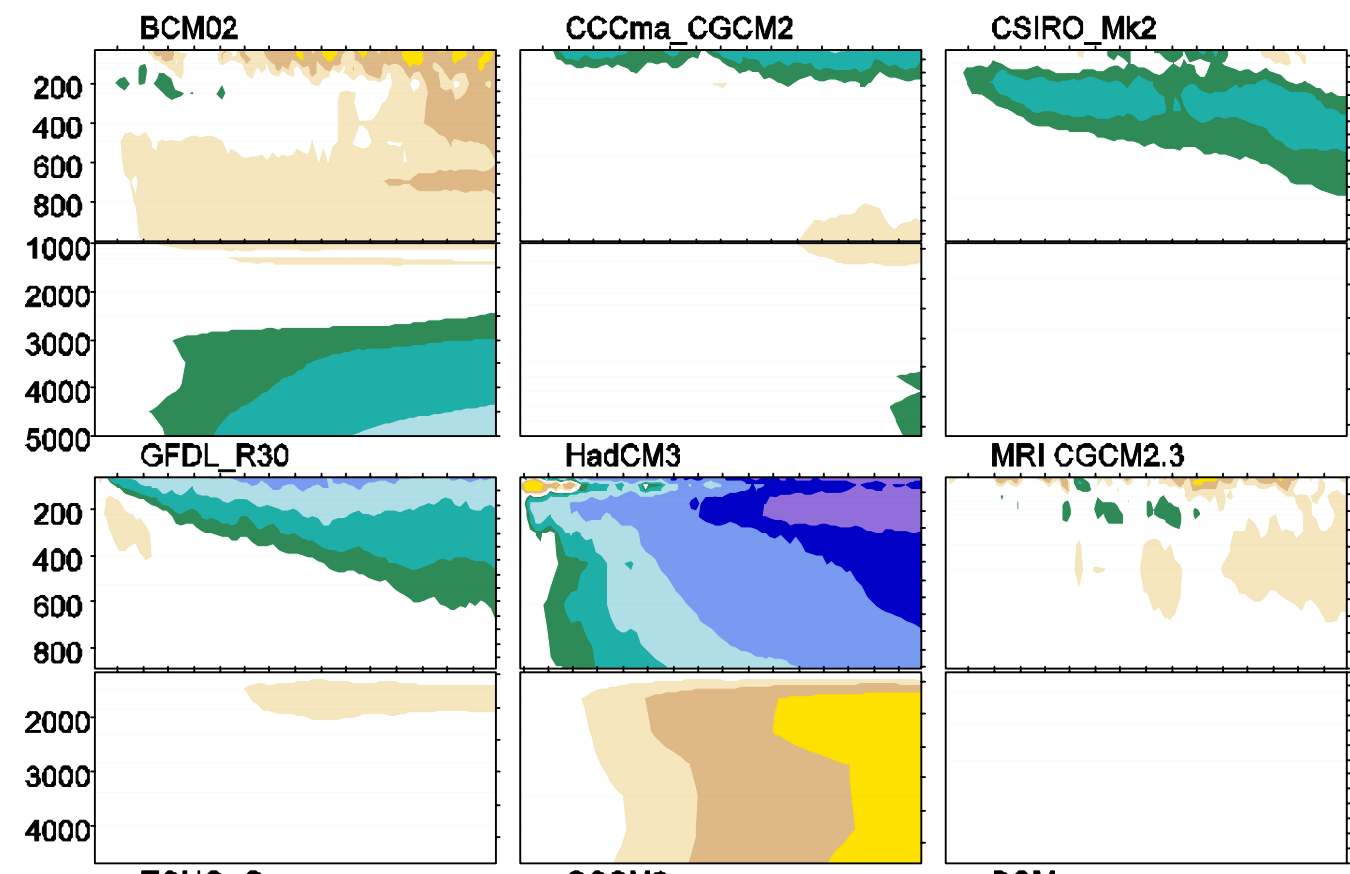

MRI CGCM2.3
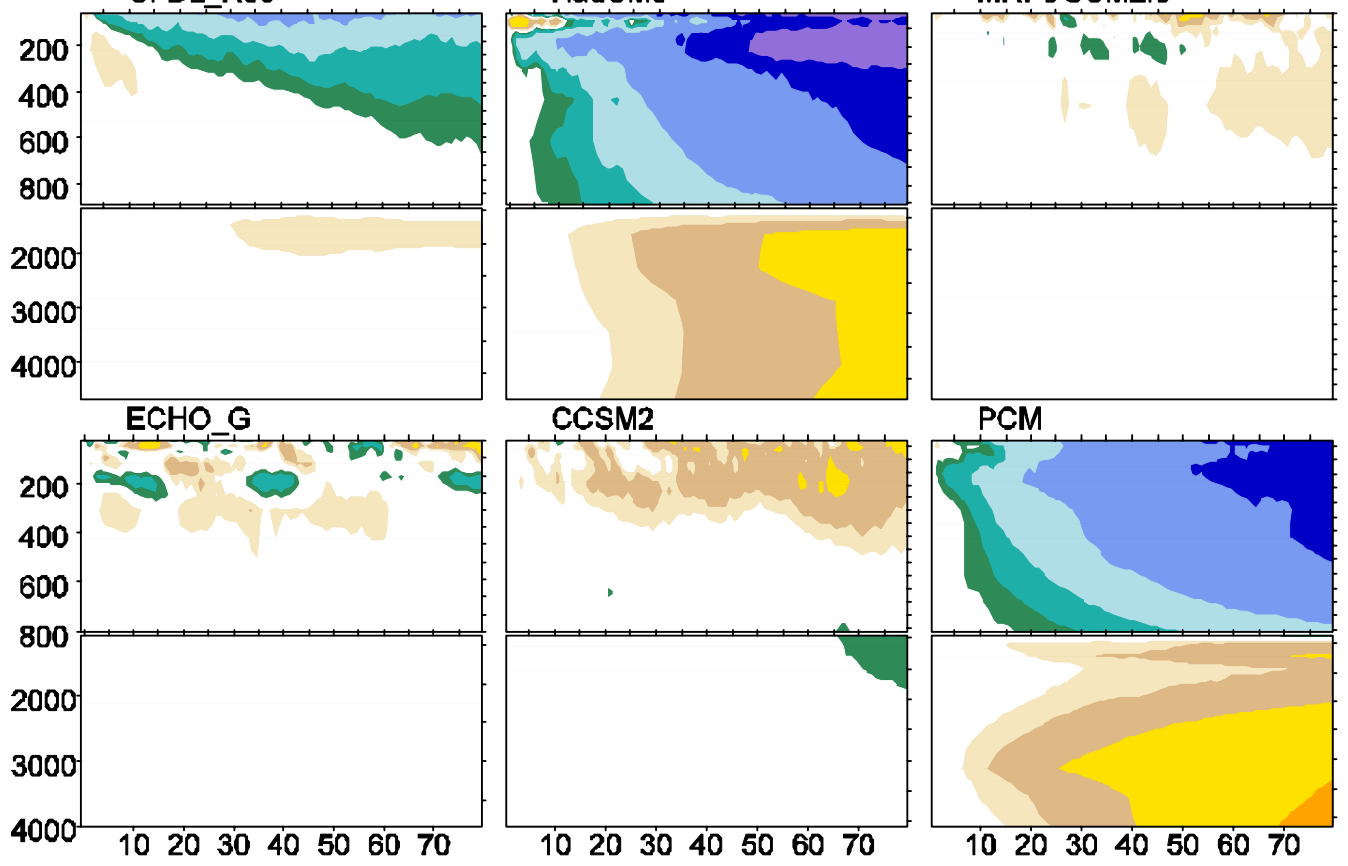

Global Ocean

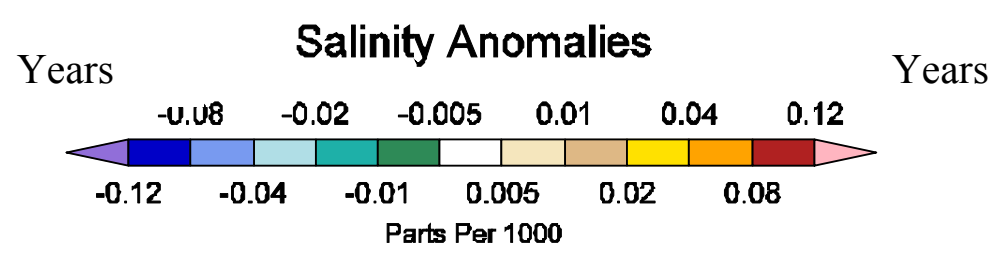

Fig. 8. Deviation of the globally and annually averaged ocean salinity from the first year (of data archived at PCMDI) as a function of depth (ppt). 

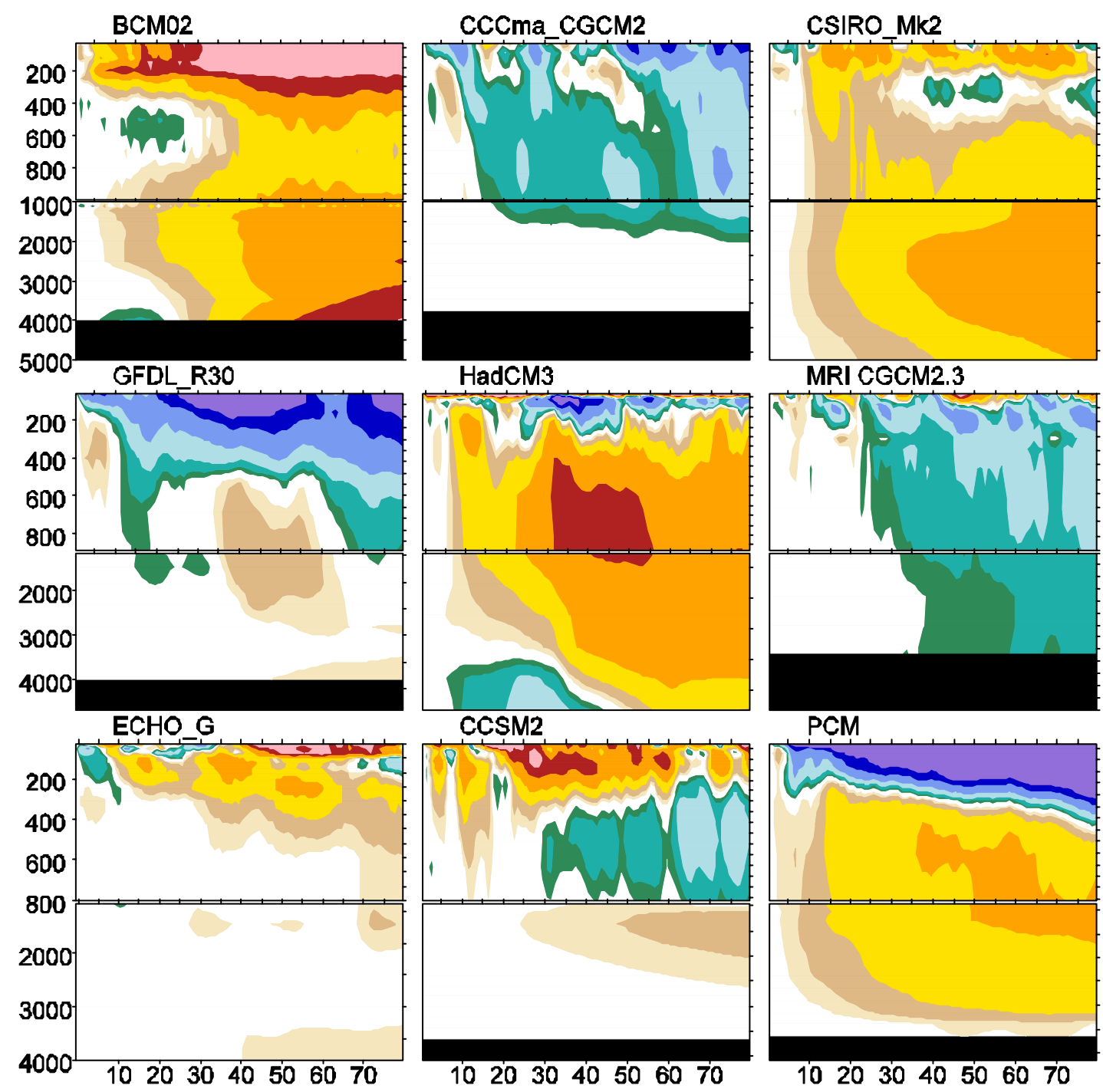

\section{Arctic Ocean}

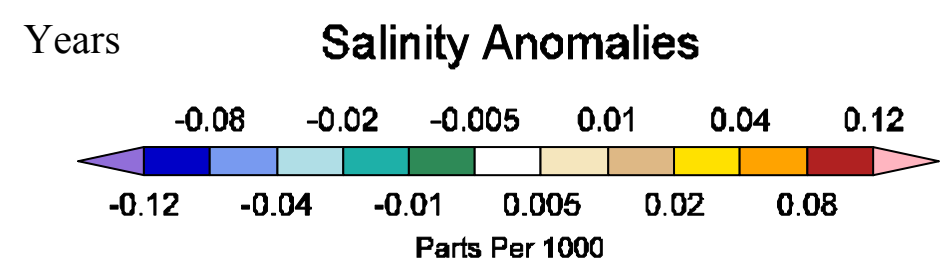

Fig. 9. Deviation of the Arctic Basin annual mean ocean salinity (ppt) from the first year (of data archived at PCMDI) as a function of depth (m). 


\section{Deviations in the Annual Mean Total Sea Ice Coverage}

$5 \mathrm{yr}$ running mean of the $\%$ change from mean of first $5 \mathrm{yrs}$
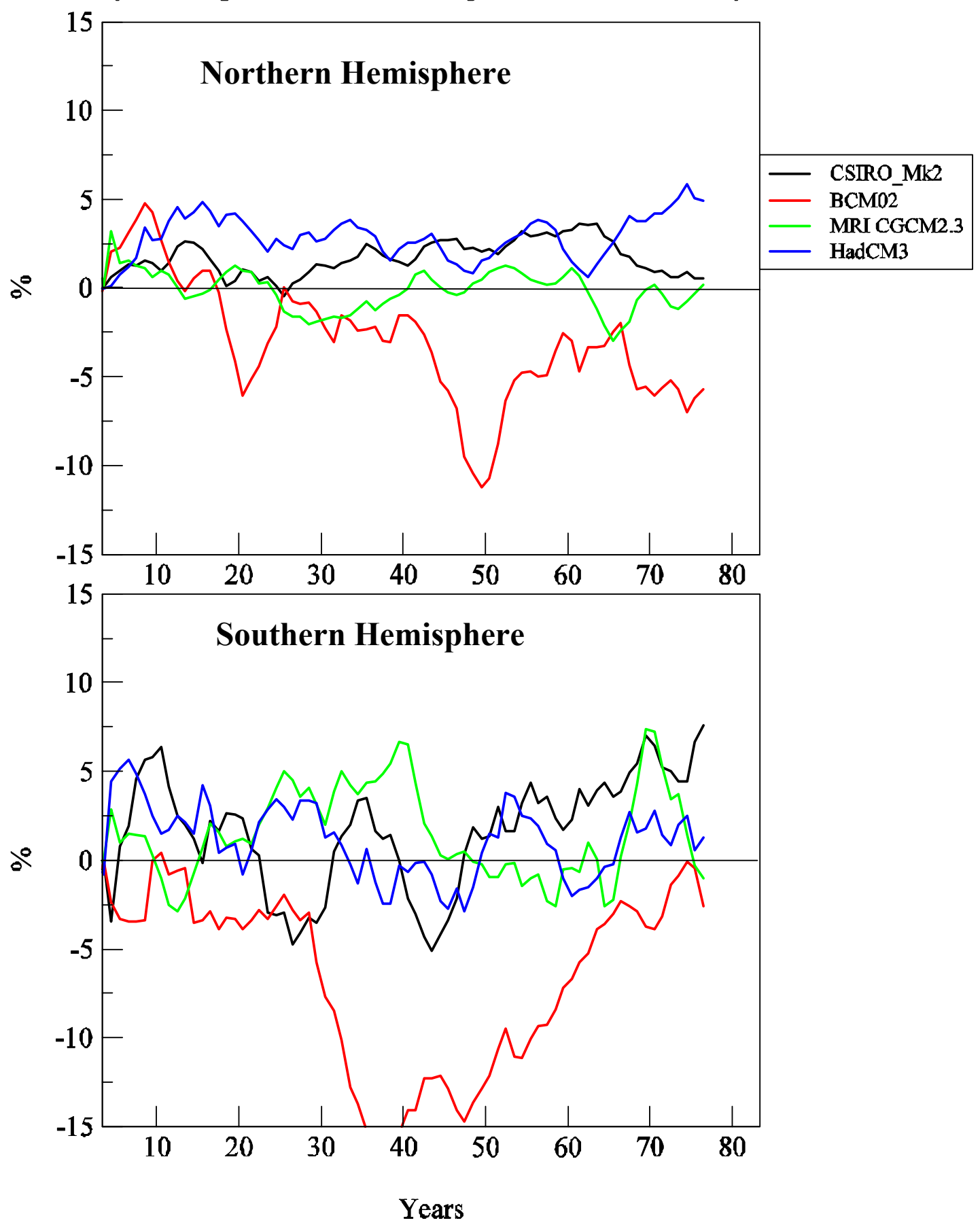

Fig. 10. Northern and Southern Hemisphere 5-year running means of the percentage changes in the total sea ice surface area with respect to the mean of the first 5 years. 